\title{
Inhibition of cyclooxygenase-2 aggravates doxorubicin-mediated cardiac injury in vivo
}

\author{
Noreen P. Dowd, ${ }^{1}$ Michael Scully, ${ }^{2}$ Sharon R. Adderley, ${ }^{2}$ Anthony J. Cunningham, ${ }^{1}$ \\ and Desmond J. Fitzgerald ${ }^{2}$
}

${ }^{1}$ Department of Anaesthesia and Intensive Care, Beaumont Hospital, Dublin, Ireland

${ }^{2}$ Centre for Cardiovascular Science, Royal College of Surgeons in Ireland, Dublin, Ireland

Address correspondence to: Desmond J. Fitzgerald, Centre for Cardiovascular Science,

Royal College of Surgeons in Ireland, St. Stephen's Green, Dublin 2, Ireland.

Phone: 353-1-4782165; Fax: 353-1-4022453; E-mail: dfitzgerald@rcsi.ie.

Received for publication September 14, 2000, and accepted in revised form July 6, 2001.

The clinical use of doxorubicin, an anthracycline chemotherapeutic agent, is limited by cardiotoxicity, particularly when combined with herceptin, an antibody that blocks the HER2 receptor. Doxorubicin induces cyclooxygenase-2 (COX-2) activity in rat neonatal cardiomyocytes. This expression of COX-2 limits doxorubicin-induced cardiac cell injury, raising the possibility that the administration of a prostaglandin may protect the heart during the in vivo administration of doxorubicin. Doxorubicin $(15 \mathrm{mg} / \mathrm{kg})$ administered to adult male Sprague Dawley rats induced COX-2 expression and activity in cardiac tissue. Prostacyclin generation measured as the excretion of 2,3-dinor-6-keto-PGF ${ }_{1 \alpha}$ also increased, and this was blocked by a COX-2 inhibitor, SC236. In contrast, administration of a COX-1 inhibitor SC560 at a dose that reduced serum thromboxane $B_{2}$ by more than $80 \%$ did not prevent the doxorubicin-induced increase in prostacyclin generation. Doxorubicin increased cardiac injury, detected as a rise in plasma cardiac troponin $\mathrm{T}$, serum lactate dehydrogenase, and cardiomyocyte apoptosis; this was aggravated by coadministration of SC236 but not SC560. The degree of injury in animals treated with a combination of doxorubicin and SC236 was attenuated by prior administration of the prostacyclin analogue iloprost. These data raise the possibility of protecting the heart during the administration of doxorubicin by prior administration of prostacyclin.

J. Clin. Invest. 108:585-590 (2001). DOI:10.1172/JCI200111334.

\section{Introduction}

Doxorubicin (DX) is an anthracycline that is a highly effective chemotherapeutic agent used largely in the treatment of solid tumors. However, the dose of DX is limited owing to a dose-related cardiac toxicity (1-3). In cardiac cells, DX is metabolized to the corresponding semiquinone free radical by flavin reductases $(4,5)$. This or a related species induces apoptosis in cardiomyocytes and is prevented by free radical-scavengers (6) or by chelating iron (7).

We have previously shown that DX induces cyclooxygenase (COX) activity in rat neonatal cardiomyocytes (8). COX catalyzes the first step in the conversion of arachidonic acid to prostaglandins (9). Two isoforms of COX have been identified that are the products of distinct genes. COX-1 is expressed in most cells and is the only isoform found in normal cardiomyocytes. COX-2 is largely absent from cells but is induced by a number of factors $(10,11)$ including presence of free radicals (8) and hypoxia (12). The differential expression of COX-1 and COX-2 in part reflects differences in the promoter structure of the two genes, with the COX-2 promoter containing the response elements of an inflammatory or acute-phase gene $(13,14)$. COX-2 expression is also regulated by modulation of mRNA stability $(15,16)$. In several types of cells, COX-2 expres- sion has been shown to protect against apoptosis (17, 18). In rat neonatal cardiomyocytes, the induction of COX activity by DX is due to COX-2 gene expression (9). Inhibition of COX-2 aggravated the injury of the cells by DX, detected as the release of LDH or as apoptosis, and a prostaglandin prevented the injury. These findings raise the possibility of protecting the heart during treatment with DX by exogenous administration of a prostaglandin. Here, we examine whether DX induces cardiac injury in vivo in the rat and whether this is regulated by prostaglandins.

\section{Methods}

DX was from Pharmacia \& Upjohn SpA (Milan, Italy). The 3,3'-diaminobenzidine tetrahydrochloride (DAB), Harris hematoxylin solution, Permount, and commonly used laboratory chemicals were obtained from Sigma Chemical Co. (St. Louis, Missouri, USA). Deuterated eicosanoid standards, NS-398, and arachidonic acid were obtained from Cayman Chemical Co. (Ann Arbor, Michigan, USA). Goat polyclonal antiCOX-1 antibody was from Oxford Biomedical Research Inc. (Rochester Hills, Missouri, USA). Monoclonal anti-mouse COX-2 antibody (R6), SC560, and SC236 were gifts from P. Isakson (Pharmacia Corp., Skokie, Illinois, USA). Immunohistochemical analysis 
kits containing secondary antibodies and reagents were from DAKO Corp. (Carpinteria, California, USA). Iloprost was obtained from Schering Aktiengesellschaff (Berlin, Germany). Enzyme immunoassays were obtained from R\&D Systems Inc. (Minneapolis, Minnesota, USA).

Model. Male Sprague Dawley rats (6-8 weeks old; 200-250 g) were studied. All experiments involving the use of rats were conducted in accordance with protocols approved by the institutional Biomedical Research Committee and with a license granted under the Cruelty to Animals Acts of 1876 by the Department of Health of Ireland. All study drugs were administered by intraperitoneal injection.

A total of $15 \mathrm{mg} / \mathrm{kg}$ of DX or an equal volume of DMSO (Sigma Chemical Co.) was injected into the intraperitoneal space. Three hours after the injection, general anesthesia was induced and maintained by inhalation of halothane $1.5 \%-2 \%$ in an animal-specific anesthetic chamber. A transverse subdiaphragmatic incision was made, and a section of diaphragm $(\sim 0.5 \times$ $0.3 \mathrm{~cm}$ ) was dissected and removed. The thoracic cage was immediately opened, and the heart was dissected from the thoracic cavity. The tissues were analyzed for prostaglandin generation or fixed in formalin saline solution $(0.9 \% \mathrm{NaCl}$ and $10 \%$ formaldehyde) for immunohistochemistry. In additional experiments, the animals were treated with the following: (a) Three milligrams per kilogram of the selective COX-2 inhibitor SC236 3, followed 1 hour later by $3 \mathrm{mg} / \mathrm{kg}$ of SC236 and $15 \mathrm{mg} / \mathrm{kg}$ of DX. (b) A total of $3-10 \mathrm{mg} / \mathrm{kg}$ of the selective COX-1 inhibitor SC560, followed 1 hour later by $3-10 \mathrm{mg} / \mathrm{kg}$ of SC560 and $15 \mathrm{mg} / \mathrm{kg}$ of DX. (c) Two milligrams per kilogram of indomethacin (a nonselective cyclooxygenase inhibitor), followed 1 hour later by $2 \mathrm{mg} / \mathrm{kg}$ of indomethacin and $15 \mathrm{mg} / \mathrm{kg}$ of DX. (d) A total of $9 \mu \mathrm{g} / \mathrm{kg}$ of iloprost in three divided doses at 12-hour intervals; after the third dose, the animals were treated as above.

Immunohistochemistry. The tissue was processed and embedded in wax using a Raymond Lamb Blockmaster II. Sections $(5-8 \mu \mathrm{m})$ were cut onto silane-coated slides. The slides were baked overnight at $37^{\circ} \mathrm{C}$ and then deparaffinized and hydrated as follows: xylene (three times for 5 minutes), 100\% ethanol (3 minutes), $90 \%$ ethanol (3 minutes), $70 \%$ ethanol (3 minutes), 50\% ethanol (3 minutes), $30 \%$ ethanol (5 minutes), Tris$\mathrm{MgCl}_{2}$ (5 minutes), and PBS (5 minutes). The slides were washed in PBS for 5 minutes and incubated in $0.3 \%$ hydrogen peroxide $\left(\mathrm{H}_{2} \mathrm{O}_{2}\right)$ in methanol for 30 minutes, to quench endogenous peroxidase activity. This was followed by three additional 5-minute washes in PBS. After blocking for 1 hour in normal serum from the species from which the secondary antibody was raised (mouse serum for Cox-1; goat for Cox-2), the slides were incubated in primary antibody (polyclonal anti-Cox- 1 antibody 1:500 or a monoclonal anti Cox- 2 1: 1500 antibody) for 1 hour and again washed three times for five minutes. All antibody incubations were performed in a moist chamber at room temperature for 1 hour. The slides were incubated in the secondary biotinylated antibody for 1 hour (ABC complex; Vectastain Elite Kit; Vector Laboratories Inc., Burlingame, California, USA), and the slides were washed in PBS. The immunocomplex was visualized using $\mathrm{DAB}+$ $0.01 \% \mathrm{H}_{2} \mathrm{O}_{2}$ for less than 10 minutes at room temperature. The slides were counterstained with hematoxylin, "blued" in running tap water for 5 minutes, cleared in xylene, and mounted in DPX mountant (BDH Laboratory Supplies, Poole, United Kingdom). The slides were visualized by a light microscope with color video attachment for recording.

Prostacyclin formation by the cardiac tissue. Three hours after intraperitoneal injection with $15 \mathrm{mg} / \mathrm{kg}$ of DX, or an equal volume of saline or DMSO, the thoracic cage was opened and the heart was removed under anesthesia as described above. Each heart was then sectioned into three segments. The first segment was placed into a test tube with Hanks' HEPES $(\mathrm{H} / \mathrm{H})$ solution and 50 $\mu \mathrm{M}$ arachidonic acid; the second segment was placed into a test tube with $\mathrm{H} / \mathrm{H}$ solution, arachidonic acid, and $1 \mu \mathrm{M}$ of a specific COX-2 inhibitor, NS 398; the third segment was placed into a test tube with $\mathrm{H} / \mathrm{H}$ solution, arachidonic acid, and $200 \mu \mathrm{M}$ of aspirin (a nonselective COX inhibitor). After 15 minutes, the supernatant in each tube was aspirated and stored at $-20^{\circ} \mathrm{C}$. The samples were analyzed for 6-ketoprostaglandin $\mathrm{F}_{1 \alpha}\left(6-\right.$ keto- $\left.\mathrm{PGF}_{1 \alpha}\right)$, the stable hydrolysis product of $\mathrm{PGI}_{2}$ by enzyme immunoassay.

Urinary excretion of prostaglandin metabolites. After injection, urine was collected over 24 hours in a metabolic cage and stored at $-20^{\circ} \mathrm{C}$ until analyzed for 2,3-dinor-6keto-PGF ${ }_{1 \alpha}$, the principal enzymatic metabolite of prostacyclin $\left(\mathrm{PGI}_{2}\right)$; for $\mathrm{PGF}_{2 \alpha}$; and for the isoprostane 8-iso-PGF $2 \alpha$ by gas chromatography/mass spectrometry. Two milliliters of urine were spiked with deuterated internal standards and allowed to equilibrate for 15 minutes. The sample was deprotonated by lowering the $\mathrm{pH}$ to 3.0 using $10 \%$ formic acid $(100 \mu \mathrm{l})$, and the samples were equilibrated for a further 30 minutes. The sample was applied to c-18 SPE cartridges, washed, and then eluted with $1.5 \mathrm{ml}$ of $10 \% \mathrm{MeOH}$ in ETOAc. The methoxylamine derivative was formed by adding $50 \mu \mathrm{l}$ of $0.5 \%$ methoxylamine in pyridine and was then incubated overnight at room temperature. The sample was dried under vacuum, resuspended in $25 \mu \mathrm{l}$ of $\mathrm{MeOH}$, and separated by thin layer chromatography (TLC) with a developing solvent of $36 \mathrm{ml}$ of ETOAc, $4 \mathrm{ml}$ of $\mathrm{MeOH}$, and $0.04 \mathrm{ml}$ of concentrated acetic acid. The sample was derivatized as the pentaflourobenzyl ester, trimethylsilyl ether for 2,3-dinor-6-keto-PGF $1 \alpha$, or t-butyl ether for 8 -iso-PGF 2 . The samples were redried under vacuum and finally resuspended in $20 \mu \mathrm{l}$ of dodecane. Quantitation was performed on a Varian 3400 gas chromatograph linked to a Finnigan Incos XL mass spectrometer (Thermo Finnigan, Whythenshawe, United Kingdom) operated in the negative ion, chemical ionization mode. The results were corrected for urinary creatinine levels. 

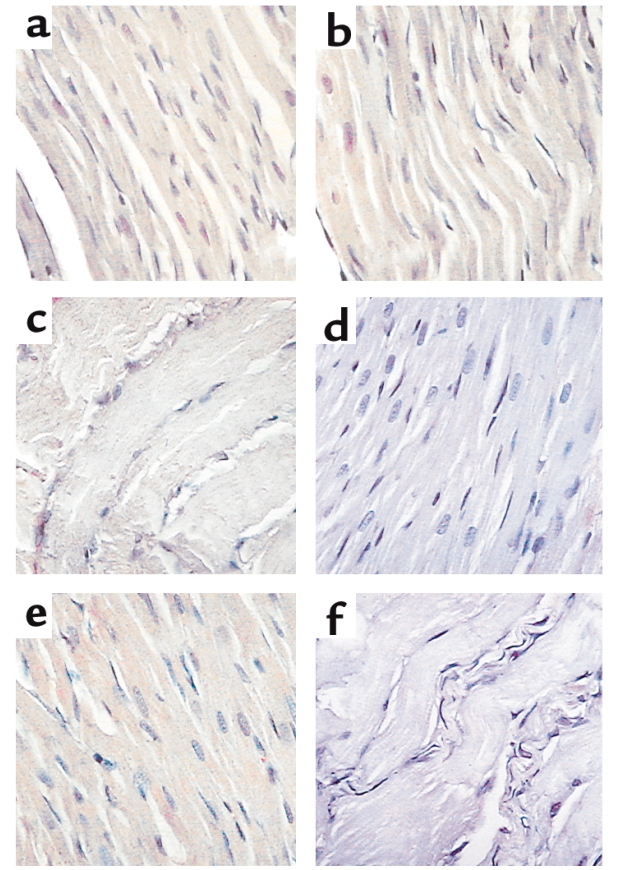

\section{Figure 1}

DX-induced COX-2 expression in cardiac tissue (representative of six to nine experiments for each treatment). COX-1 is constitutively expressed in cardiomyocytes in vehicle-treated control animals (a) and after DX injection (b), and in the myocytes of the diaphragm (c). COX-2 is not detected in hearts from vehicle-treated controls (d) but is induced 4 hours after administration of DX (e). COX-2 is not detected in the diaphragm after DX administration (f).

Serum thromboxane $B_{2}$. A dose response of SC560induced inhibition of serum thromboxane $\mathrm{B}_{2}$, an assay of COX-1 activity, was established before the experiments. Animals were injected intraperitoneally with $3 \mathrm{mg} / \mathrm{kg}$ of $\operatorname{SC} 560(n=3), 10 \mathrm{mg} / \mathrm{kg}$ of SC560 $(n=6), 3 \mathrm{mg} / \mathrm{kg}$ of SC236 $(n=3)$, or vehicle alone $(n=3)$. Four hours after injection, $1-\mathrm{ml}$ aliquots of blood were sampled from the jugular vein into glass tubes and allowed to clot at $37^{\circ} \mathrm{C}$ for 1 hour. The plasma was separated by centrifugation (900 $\mathrm{g}$ for $10 \mathrm{minutes}$ ) and stored at $-70^{\circ} \mathrm{C}$ until assayed for thromboxane $\mathrm{B}_{2}$ by enzyme immunoassay.

Serum cardiac troponin T. Myocardial injury was detected by measuring cardiac troponin $\mathrm{T}$ (CTnT) and lactate dehydrogenase (LDH) levels in serum from venous blood samples. Blood from the jugular vein was sampled at 4 hours. The blood samples were centrifuged, and the serum was stored at $-20^{\circ} \mathrm{C}$ until analyzed. $\mathrm{CTnT}$ levels were measured by enzyme immunoassay using an ES300 troponin T assay kit (Boehringer Mannheim Immunodiagnostics, Mannheim, Germany), with a lower limit of detection of $0.01 \mathrm{ng} / \mathrm{ml}$. $\mathrm{LDH}$ levels were measured by ultraviolet photometric assay (Roche Diagnostics Ltd., Lewes, United Kingdom) with a lower detection point of $6 \mathrm{U} / \mathrm{l}$.

TUNEL assay. TUNEL assay was performed to detect apoptosis in cardiac sections. Briefly, after pretreatment with proteinase $\mathrm{K}(20 \mu \mathrm{g} / \mathrm{ml})$ and $3.0 \%$ hydrogen peroxide, paraffin-fixed slides were treated with a digoxigenin-dNTP complex for 1 hour at $37^{\circ} \mathrm{C}$ (ApopTag; Intergen Co., Oxford, United Kingdom). This complex binds to free 3-OH termini of nucleosomesized DNA fragments that are formed during apoptosis, and it is detected by anti-digoxigenin conjugate antibody. The bound complex stained with a DABbased substrate. The slides were counterstained with $0.5 \%$ methyl green in $0.1 \mathrm{M}$ sodium acetate, dehydrated in xylene, and mounted and examined by light microscopy. Examination of the slides was performed by two observers (one blinded) who counted the total number of apoptotic and normal cells over 25 highpowered fields for each slide using an ocular grid $(0.25$ $\mathrm{mm}^{2}$ area of field). The number of apoptotic cells was expressed as the percent of the total number of cells.

Statistical analysis. All quantitative data are expressed as mean \pm SEM. The data were analyzed by ANOVA and subsequently, where appropriate, by paired analysis.

\section{Results}

DX induces COX-2 isoform expression in the heart. Immunohistochemistry showed constitutive expression of COX1 in cardiac cells and in the myocytes of the diaphragm. COX-2 was absent from the normal heart but was induced 4 hours after the administration of DX (Figure 1). In contrast, COX-2 expression was absent in the diaphragm of DX-treated rats. These findings were confirmed by assay of COX activity, detected as the generation of $\mathrm{PGI}_{2}$, the main product in myocardial tissue. Myocardial biopsies from DX- and vehicle-treated rats were exposed to arachidonic acid ex vivo, and the levels of 6-keto-PGF ${ }_{1 \alpha}$, the hydrolysis product of $\mathrm{PGI}_{2}$, was measured in the supernatant. The concentration of 6keto-PGF ${ }_{1 \alpha}$ was higher in the DX-treated rats compared with vehicle-treated controls $(P=0.02$; Figure 2$)$. The increase in 6-keto-PGF ${ }_{1 \alpha}$ formation was reduced in the presence of NS 398, the selective COX-2 inhibitor, or aspirin, the nonselective COX inhibitor. NS 398 had no effect on the generation of 6-keto-PGF ${ }_{1 \alpha}$ by myocardial tissue from vehicle-treated animals.

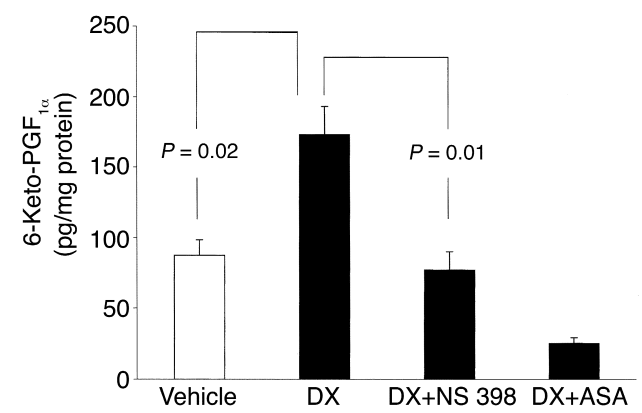

Figure 2

Generation of prostacyclin-measured 6-keto-PGF $1 \alpha$ in cardiac tissue after DX administration. The increase in 6-keto-PGF ${ }_{1 \alpha}$ formation after DX administration was reduced by $1 \mu \mathrm{M}$ of the selective COX-2 inhibitor NS 398 and by $200 \mathrm{nM}$ of aspirin (ASA) (data are expressed as the mean \pm SEM of six separate experiments per treatment). 


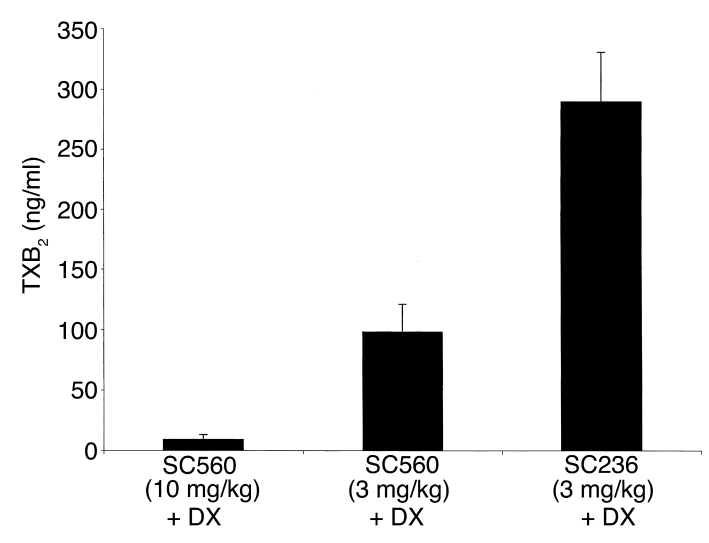

Figure 3

Dose-dependent inhibition of serum thromboxane $B_{2}$ by SC560 (the data are expressed as the mean \pm SEM of $n=3$ for each treatment).

Generation of prostaglandins in vivo. To determine whether DX increased eicosanoid generation in vivo and identify the COX isoform responsible, we examined their urinary excretion of prostaglandins in the presence and absence of selective inhibitors SC236 (for COX-2) and SC560 (for COX-1). Given that SC560 is highly selective but not specific for COX-1 in some species, a dose response for SC560-induced inhibition of serum thromboxane $\mathrm{B}_{2}$, an assay of COX-1 activity, was established before the experiments (Figure 3). Administration of $10 \mathrm{mg} / \mathrm{kg}$ SC560 reduced the serum thromboxane $\mathrm{B}_{2}$ by more than $80 \%$ (290 \pm 42 to $18.5 \pm$ $9.8 \mathrm{ng} / \mathrm{ml} ; P<0.001)$, and this dose was used in subsequent experiments. In contrast, the COX-2 inhibitor SC236 had no effect on serum thromboxane $B_{2}(290 \pm$ 42 to $224 \pm 90 \mathrm{ng} / \mathrm{ml} ; P=\mathrm{NS})$. $\mathrm{PGI}_{2}$ production in vivo was quantified as the excretion of 2,3-dinor 6-keto$\mathrm{PGF}_{1 \alpha}$, its major enzymatic metabolite. Urinary 2,3dinor 6-keto-PGF ${ }_{1 \alpha}$ increased after the administration of DX (Figure 4). The increase in 2,3-dinor 6-keto$\mathrm{PGF}_{1 \alpha}$ was abolished by the administration of the selective COX-2 inhibitor SC236. A similar effect was seen with the nonselective COX inhibitor indomethacin. The selective COX-1 inhibitor SC560 induced a small reduction in urinary 2,3 -dinor 6 -keto-PGF - $_{1 \alpha}$, probably reflecting inhibition of $\mathrm{PGI}_{2}$ generated by constitutively expressed COX-1. However, SC560 did not prevent the increase in $\mathrm{PGI}_{2}$ induced by DX (Figure 4). A similar trend was seen with urinary $\mathrm{PGF}_{2 \alpha}$, although none of the changes were statistically significant. There was a small, although not significant, increase in the excretion of the isoprostane 8 -iso-PGF $2 \alpha$ (from $2.02 \pm 0.2$ to $3.3 \pm 2.1 \mathrm{ng} / \mathrm{mg}$ creatinine), a marker of gross free-radical-induced injury.

Cardiac injury. Myocardial injury was evaluated by measuring CTnT in venous blood. No measurable CTnT was detected in animals treated with vehicle, SC236, or SC560 alone. CTnT levels increased in the DX-treated rats, and the levels increased further when DX was combined with the COX-2 inhibitor SC236 (Figure 5). Similar results were seen with plasma LDH, which increased with DX $(578 \pm 227 \mathrm{U} / 1 ; n=6)$ and was further increased when DX was combined with SC236 (1,552 $\pm 58 \mathrm{U} / \mathrm{l}$; $n=3, P=0.02)$, versus $156 \pm 28 \mathrm{U} / 1(n=6)$ in untreated controls. The CTnT levels were not further increased when DX was combined with the COX-1 inhibitor SC560. We examined whether the enhanced injury seen when DX was combined with SC236 could be offset by $\mathrm{PGI}_{2}$, administered as its stable analogue iloprost. No measurable concentrations of CTnT were detected in seven of 12 rats injected with iloprost combined with DX (Figure 5). DX also increased the percentage of apoptotic cells detected as TUNEL-positive cells (Figure 6). A further increase was seen when DX was combined with SC236, and the effect of the combination was attenuated by prior treatment with iloprost.

\section{Discussion}

COX-2 expression in several cells, but particularly cancer cell lines, appears to protect against apoptosis and to promote cell growth $(17,18)$. Thus, COX-2 inhibition suppresses the growth of tumor cells in vitro (19) and inhibits tumor formation in the $A P C$ knockout mouse model of colon cancer (20) and in human familial polyposis coli (21). COX-2 is expressed in areas of infarction in the human heart (22), and myocardial COX-2 expression has been reported in the rat heart during cardiac transplant rejection (23). In addition, cardiac fibrosis has been reported in the COX-2-knockout mouse (24). Together, these findings prompted us to examine whether COX-2 was protective in cardiomyocytes in vitro. Cardiomyocytes only express COX-1 under normal circumstances, but COX-2 was induced on exposure to free radicals or DX (9). DX also provoked the release

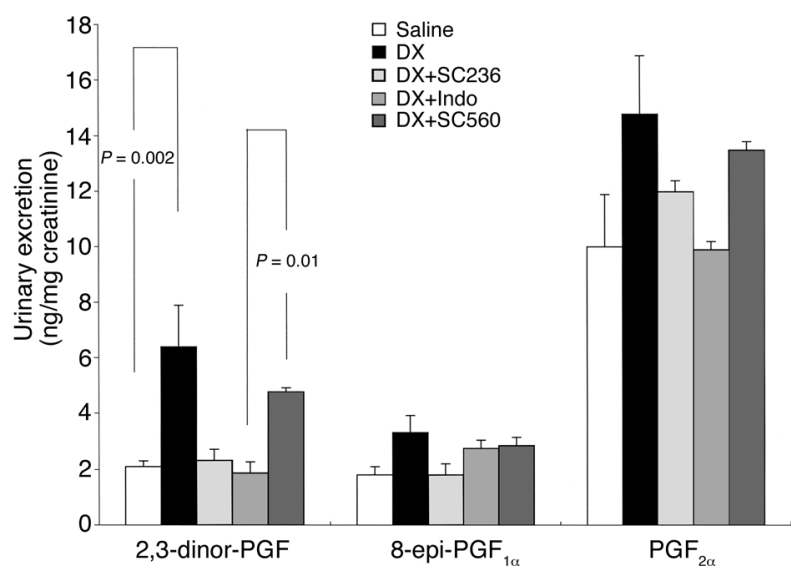

\section{Figure 4}

Urinary excretion of 2,3-dinor 6-keto-PGF $1 \alpha$, 8-iso-PGF $2 \alpha$, and $\mathrm{PGF}_{2 \alpha}$, after the administration of DX. The increase in 2,3-dinor 6-keto$\mathrm{PGF}_{1 \alpha}$ was inhibited by the administration of the selective COX-2 inhibitor SC236 and by indomethacin (Indo), whereas the selective COX-1 inhibitor SC 560 had little effect. A similar trend was seen with urinary $\mathrm{PGF}_{2 \alpha}$, although none of the changes were statistically significant. (The results are the mean \pm SEM of five separate experiments for each treatment.) 


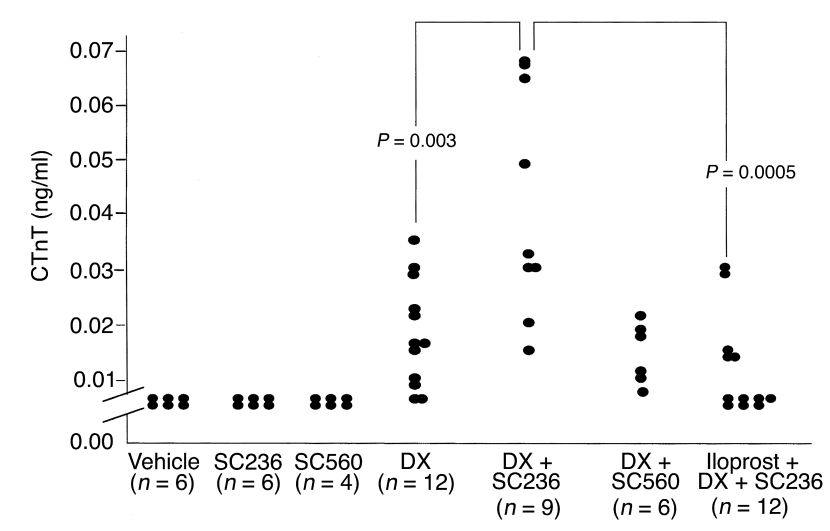

Figure 5

Cardiac injury detected as an increase in CTnT of more than 0.01 $\mathrm{ng} / \mathrm{ml}$, after DX administration alone and combined with the selective COX-2 inhibitor SC236. DX induced cardiac injury, and this was aggravated by SC236 but not SC 560 . The increase in injury seen with the combination of DX and SC236 was attenuated by prior administration of iloprost, a stable analogue of $\mathrm{PGI}_{2}$.

of LDH and increased the rate of apoptosis (S.R. Adderley and D.J. Fitzgerald, unpublished data), and this was aggravated by a COX-2 inhibitor.

These in vitro data raise the possibility of protecting the heart in patients during the administration of DX by coadministration of a prostaglandin. Here, we show that DX induces COX-2 in the adult rat heart when administered exogenously and enhances the generation of $\mathrm{PGI}_{2}$, the principal product generated in cardiac cells. The isoform responsible for the increased product formation was assessed using specific inhibitors of COX isoforms (25). We have confirmed the selectivity of the compounds using COS cells expressing either COX-1 or COX-2 (data not shown). In addition, at the dose used SC236 had no effect on serum thromboxane $\mathrm{B}_{2}$, an assay of COX-1 activity. In contrast, SC560 induced a greater than $80 \%$ inhibition of serum thromboxane $\mathrm{B}_{2}$. SC236 prevented the rise in urinary 2,3-dinor-6-keto-PGF ${ }_{1 \alpha}$ seen with DX, demonstrating a role for COX-2 in the enhanced generation of $\mathrm{PGI}_{2}$ after administration of the anthracycline. In contrast, SC560 had very little effect.

DX administered alone induced cardiac injury measured as the increase in serum CTnT and by the number of apoptotic cells detected on TUNEL assay, as reported previously $(26,27)$. Coadministration of SC236 aggravated the cardiac injury, whereas the COX-1 inhibitor did not. There is evidence that COX-2 inhibitors enhance apoptosis in some cell lines in a prostaglandin-independent manner (28). Moreover, some NSAIDs (although not COX-2 inhibitors) inhibit a multidrugresistance protein responsible for transporting DX out of cells (29). However, administration of an analogue of $\mathrm{PGI}_{2}$, the major product of the cardiomyocytes, prevented the injury. Further, in five of the 12 animals, there was still evidence of cardiac injury despite treatment with iloprost. This may reflect additional mechanisms of cell death induced by DX that are not reversed by iloprost, although, in the absence of dose-response data, the mechanism is unclear. Mass spectrometry of cell supernatants show that cardiomyocytes largely generate $\mathrm{PGI}_{2}$ in addition to $\mathrm{PGF}_{2 \alpha}$ and $\mathrm{PGE}_{2}$. In vitro, only $\mathrm{PGI}_{2}$ protected against DX-mediated injury (8), suggesting that this may be the product responsible for the cytoprotective effect of COX-2 expression. Prostaglandins, however, can have the opposite effect. Thus, expression of COX-2 enhances apoptosis in neuronal cells (30) and the $\mathrm{PGD}_{2}$ metabolite 15-deoxy $\mathrm{PGJ}_{2}$ provokes endothelial cell death (31). Thus, the effect may be specific to prostacyclin or its analogues.

Prostaglandins act on two classes of receptors (a) surface transmembrane-spanning, G-protein-coupled receptors and (b) PPARs, which are nuclear membrane receptors. Prostaglandins and their precursors are ligands for several PPARs including PPAR $\alpha$ (polyunsaturated fatty acids), $\operatorname{PPAR} \delta\left(\mathrm{PGI}_{2}\right)$, and $\operatorname{PPAR} \gamma\left(\mathrm{PGD}_{2}, 15-\right.$ deoxy $\mathrm{PGJ}_{2}$ ) (31). PPAR $\alpha$ and PPAR $\delta$ are widely expressed in tissues including the heart, whereas PPAR $\gamma$ is found particularly in adipocytes (32). PPARs heterodimerize with other proteins, such as the retinoid $X$ receptor and ARA70, to act as transcription factor complexes for a wide number of genes, particu-

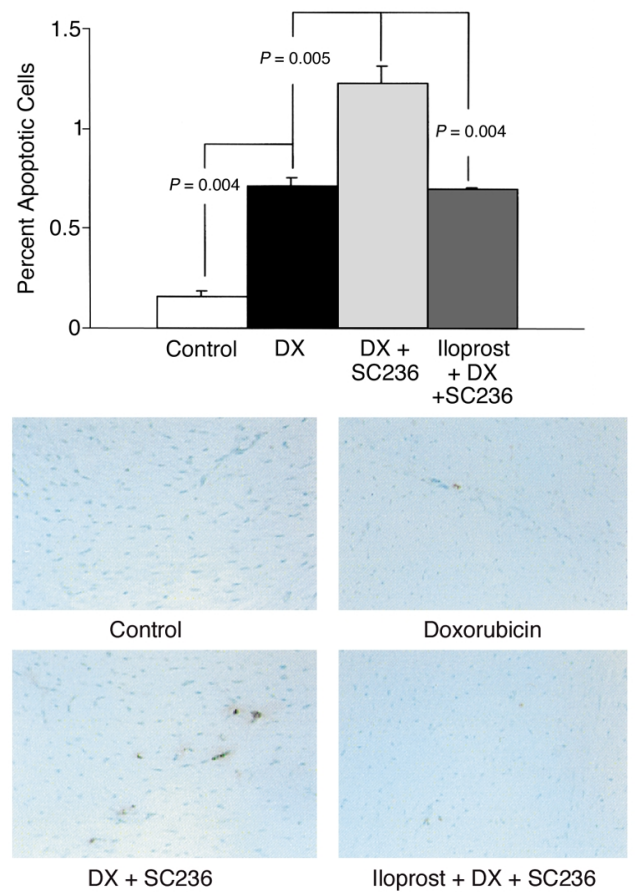

Figure 6

Cardiac injury detected as apoptosis (TUNEL-positive cells) after DX treatment alone and combined with the selective COX-2 inhibitor SC236. DX increased the percentage of cells that were apoptotic at 4 hours, and this was further aggravated by SC236. The increase in apoptosis seen with the combination of DX and SC236 was attenuated by prior administration of iloprost. Similar results were seen at 12 hours after DX administration (data not shown). The data are the mean ( \pm SEM) of 25 high-power fields from three to four experiments per treatment. 
larly those involved in lipid metabolism $(33,34)$. Alternatively, the effects of iloprost may be mediated through surface membrane receptors, transcripts for which have been identified in the adult human heart (35). Moreover, we cannot exclude the possibility that a vasodilator response to iloprost may have provided some degree of protection. However, the dose used was low relative to that reported to reduce blood pressure and increase heart rate in the rat (36).

In the rat model of DX-induced cardiotoxicity, COX-2 expression may provide some degree of protection against the injury induced by the anthracycline. Our experiments suggest that administration of a prostacyclin analogue may afford cardiac protection in this setting.

\section{Acknowledgments}

We thank P. Isakson for the generous gift of the monoclonal anti-mouse COX-2 antibody (R6) and Elaine Kay and Mohommad Mabruk for their support on TUNEL assays and immunohistochemistry. This work was supported by grants from the Health Research Board and Higher Education Authority of Ireland.

1. Singal, P.K., Iliskovic, N. 1998. Doxorubicin-induced cardiomyopathy. N. Engl. J. Med. 339:900-905.

2. Feldman, A.M., Lorell, B.H., Reis, S.E. 2000. Trastuzumab in the treatment of metastatic breast cancer: anticancer therapy versus cardiotoxicity. Circulation. 102:272-274.

3. Slamon, D.J., et al. 2001. Use of chemotherapy plus a monoclonal antibody against HER2 for metastatic breast cancer that overexpresses HER2. N. Engl. J. Med. 344:783-792.

4. Boveris, A. 1977. Mitochondrial production of superoxide radical and hydrogen peroxide. Adv. Exp. Med. Biol. 78:67-82.

5. Bachur, N.R., Gordon, S.C., and Gee, M.V. 1977. Anthracycline antibiotic augmentation of microsomal electron transport and free radical formation. Mol. Pharmacol. 13:901-910.

6. Della-Torre, P. 1996. Long-lasting effect of dexrazoxone against anthracycline cardiotoxicity in rats. Toxicol. Pathol. 24:398-402.

7. Sparano, J.A. 1998. Use of dexrazoxane and other strategies to prevent cardiomyopathy associated with doxorubicin-taxane combinations. Semin. Oncol. 25(Suppl. 10):66-71.

8. Adderley, S., and Fitzgerald, D. 1999. Oxidative damage of cardiomyocytes is limited by extracellular regulated kinases $1 / 2$-mediated induction of cyclooxygenase 2. J. Biol. Chem. 27:5038-5046.

9. Hemler, M., Lands, W.E.M., and Smith, W.L. 1976. Purification of cyclooxygenase that forms prostaglandins. J. Biol. Chem. 251:5575-5579.

10. Hla, T., and Neilson, K. 1992. Human cyclooxygenase-2 cDNA. Proc. Natl. Acad. Sci. USA. 89:7384-7388.

11. Kujubu, D.A., and Herschman, H.R. 1992. Dexamethasone inhibits mitogen induction of the TIS10 prostaglandin synthase/cyclooxygenase gene. J. Biol. Chem. 267:7991-7994.

12. Schmedtje, J.F., Jr, Ji, Y.S., Liu, W.L., DuBois, R.N., and Runge, M.S.J. 1997. Hypoxia induces cyclooxygenase-2 via the NF-kappaB p65 transcription factor in human vascular endothelial cells. J. Biol. Chem. 272:601-608.

13. Xie, W., and Herschman, H.R. 1995. v-src induces prostaglandin synthase 2 gene expression by activation of the c-Jun $\mathrm{N}$-terminal kinase and the c-Jun transcription factor. J. Biol. Chem. 270:27622-27628.

14. Xie, W., Fletcher, B.S., Andersen, R.D., and Herschman, H.R. 1994. Mol $\mathrm{v}$-src induction of the TIS10/PGS2 prostaglandin synthase gene is medi- ated by an ATF/CRE transcription response element. Cell Biol. 14:6531-6539.

15. Dixon, D.A., Kaplan, C.D., McIntyre, T.M., Zimmerman, G.A., and Prescott, S.M. 2000. Post-transcriptional control of cyclooxygenase-2 gene expression. The role of the $3^{\prime}$-untranslated region. J. Biol. Chem. 275:11750-11757.

16. Sheng, H., et al. 2000. Transforming growth factor-beta1 enhances Haras-induced expression of cyclooxygenase- 2 in intestinal epithelial cells via stabilization of mRNA. J. Biol. Chem. 275:6628-6635.

17. Kinoshita, T., et al. 1999. Growth stimulation and induction of epidermal growth factor receptor by over expression of cyclooxygenases 1 and 2 in human colon carcinoma cells. Biochim. Biophys. Acta. 1438:120-130.

18. Kawamura, T., et al. 1999. Prostaglandin E1 transported into cells blocks the apoptotic signals induced by nerve growth factor deprivation. J. Neurochem. 72:1907-1914.

19. Liu, X.H., Yao, S., Kirschenbaum, A., and Levine, A.C. 1998. NS398, a selective cyclooxygenase- 2 inhibitor, induces apoptosis and down-regulates bcl-2 expression in LNCaP cells. Cancer Res. 58:4245-4249.

20. Oshima, M., et al. 1996. Suppression of intestinal polyposis in Apc delta716 knockout mice by inhibition of cyclooxygenase 2 (COX-2). Cell. 87:803-809.

21. Steinbach, G., et al. 2000. The effect of celecoxib, a cyclooxygenase-2 inhibitor, in familial adenomatous polyposis. N. Engl. J. Med. 342:1946-1952.

22. Wong, S.C.Y., Mitsumasa, F., Melnyk, P., Rodger, I., and Giaid, A. 1998. Induction of cyclooxygenase- 2 and activation of nuclear factor-kB in myocardium of patients with congestive heart failure. Circulation. 98:100-103.

23. Yang, X., et al. 2000. Upregulation of COX-2 during cardiac allograft rejection. Circulation. 101:430-438.

24. Dinchuk, J.E., et al. 1995. Renal abnormalities and an altered inflammatory response in mice lacking cyclooxygenase II. Nature. 378:406-409.

25. Smith, C.J., et al. 1998. Pharmacological analysis of cyclooxygenase-1 in inflammation. Proc. Natl. Acad. Sci. USA. 95:13313-13318.

26. Herman, E.H., et al. 1998. Use of cardiac troponin T levels as an indicator of doxorubicin-induced cardiotoxicity. Cancer Res. 58:195-197.

27. Kang, Y.J., Zhou, Z.X., Wang, G.W., Buridi, A., and Klein, J.B. 2000. Suppression by metallothionein of doxorubicin-induced cardiomyocyte apoptosis through inhibition of $\mathrm{p} 38$ mitogen-activated protein kinases. J. Biol. Chem. 275:13690-13698.

28. Hsu, A.L., et al. 2000. The cyclooxygenase- 2 inhibitor celecoxib induces apoptosis by blocking Akt activation in human prostate cancer cells independently of Bcl-2. J. Biol. Chem. 275:11397-11403.

29. Duffy, C.P., et al. 1998. Enhancement of chemotherapeutic drug toxicity to human tumour cells in vitro by a subset of non-steroidal antiinflammatory drugs (NSAIDs). Eur. J. Cancer. 34:1250-1259.

30. Hewett, S.J., Uliasz, T.F., Vidwans, A.S., and Hewett, J.A. 2000. Cyclooxygenase- 2 contributes to $\mathrm{N}$-methyl-D-aspartate-mediated neuronal cell death in primary cortical cell culture. J. Pharmacol. Exp. Ther. 293:417-425.

31. Bishop-Bailey, D., and Hla, T. 1999. Endothelial cell apoptosis induced by the peroxisome proliferator-activated receptor (PPAR) ligand 15deoxy-Delta12, 14-prostaglandin J2. J. Biol. Chem. 274:17042-17048.

32. Forman, B.M., Chen, J., and Evans, R.M. 1997. Hypolipidemic drugs, polyunsaturated fatty acids, and eicosanoids are ligands for peroxisome proliferator-activated receptors alpha and delta. Proc. Natl. Acad. Sci. USA. 94:4312-4317.

33. Braissant, O., Foufelle, F., Scotto, C., Dauca, M., and Wahli, W. 1996. Differential expression of peroxisome proliferator-activated receptors (PPARs): tissue distribution of PPAR-alpha, -beta, and -gamma in the adult rat. Endocrinology. 137:354-366.

34. Heinlein, C.A., Ting, H.J., Yeh, S., and Chang, C. 1999. Identification of ARA70 as a ligand-enhanced coactivator for the peroxisome proliferator-activated receptor gamma. J. Biol. Chem. 274:16147-16152.

35. Nakagawa, O., et al. 1994. Molecular cloning of human prostacyclin receptor $\mathrm{CDNA}$ and its gene expression in the cardiovascular system. Circulation. 90:1643-1647.

36. Steinberg, H., Medvedev, O.S., Luft, F.C., and Unger, T. 1988. Effect of a prostacyclin derivative (iloprost) on regional blood flow, sympathetic nerve activity, and baroreceptor reflex in the conscious rat. J. Cardiovasc. Pharmacol. 11: 84-89. 